\title{
Designing Materials of Writing Analytical Exposition Text for Teaching English in Senior High School
}

\author{
Uray Siti Annisa Ravi Ardha, Ikhsanudin Ikhsanudin, Luwandi Suhartono \\ Universitas Tanjungpura, Pontianak \\ urayardha@gmail.com
}

\begin{abstract}
One of the texts studied by eleventh-grade students is analytical exposition text, and they are asked to produce the analytical exposition text by themselves. However, they faced some difficulties that impede their teaching and learning of making the analytical exposition text. This research aimed to design Materials of Writing Analytical Exposition Text (MOWAET) as a supplementary teaching material to support teaching and learning analytical exposition text. This research was developmental research and applied ADDIE as the procedure to design the materials. Still, there were only three implemented phases in this research: analyzing, designing, and developing. MOWAET was the completed design product for teaching-learning analytical exposition text. To do the analyzing phase,the researcher interviewed an English teacher of SMA Negeri 4 Pontianak. MOWAET was created by using PowerPoint and Animaker as the supporting software. The researcher used an internal evaluation to ensure that the product is usable in the development phase. The internal evaluation phase showed that MOWAET met all the criteria, including the objectives, the content, and the media option. In conclusion, itwas found thatthe materials of writing analytical exposition text (MOWAET) are usable to support teaching and learning analytical exposition text.
\end{abstract}

Keywords:Development Research, Materials of Writing Analytical Exposition Text (MOWAET), Analytical Exposition Text

\section{INTRODUCTION}

English is the language that has been recognized and agreed to its position as an international language. It is an introductory language that is widely used in many aspects. As a foreign language, students need to master four balanced English skills. They are listening, speaking, reading, and writing. Writing is an activity where the writers pour their ideas, thoughts, suggestions, or feelings into written form. It is one of the productive skills that students use to express their feeling or ideas.According to Ratnaningsih (2016), writing is not only writing a sentence, but it is an activity of producing a text in a context. It means that besides having the skills while writing, the learners should take place within a context.

One of the texts studied by eleventh-grade students is AnalyticalExposition Text. It is a text which evaluates a topic critically but focuses only on one side of the arguments. In the 2013curriculum, this material's learning objectivesexpect students to make analytical exposition by themselves. Then ultimately, students have to convey the contents of the text by giving a speech. Nevertheless, they faced some difficulties while producing the text. 
The researcher found that students were less enthusiastic about learning analytical exposition text. It could be seen when the teacher explained the materials, the students were busy themselves, not paying attention to the teacher's explanation - coupled with the schedule of English subjects that were placed during the day. It was because students were not involved in the learning process, and the activity was only done by giving a speech. Students would not listen and focus on learning due to sleepiness was also one of the reasons.

Teaching material also became one reason why students did not pay much attention to the learning process. While teaching the students, the teacher only used Student Worksheet (LKS), in which the book only provided brief information related to the learning material that they would learn. For example, the Students Worksheet provided the generic structure of analytical exposition text, but it did not give further explanation and examples for each point of generic structures; it only offered a list of generic structures in general. The exercises provided were also limited, especially for writing exercises, and it was for one full semester. There was no other supplementary or additional teaching material to increase students' comprehension of the material and supporting the learning process. Meanwhile, when delivering the material, the teachers need something to attract student's attention towards the material and involve students in the teaching-learning activity. Thus, the learning process needed is a learning process that can excite students; in other words, the teaching-learning activity is not dull and practical for the teacher and the students.

Therefore, technology comes for the solution with its benefit. According to Ang and Mohammad (2014), technology had improved learning in terms of efficiency, flexibility through multidimensional approach, and learner performance; hence, the learner has access to a larger quantity and better quality of information. Teaching and learning activity becomes more effective and efficient with the help of technology. In some cases, the use of technology also makes students more enthusiastic about learning. It makes presenting the material more accessible, and the use of media in the teaching and learning process makes it more fun.

The development of technology helps learning media become more comfortable to use. The use of media in learning can help students understand something abstract to be concrete, and something becomes easy. It can also stimulate thoughts, feelings, attention, and learning skill to encourage a more effective learning process. Based on Joshi (2012), using print, film, and Internet as resources for studying provides students with opportunities to gather information through stimuli that will stimulate their imaginations, engage their interest, and introduce them to the raw materials for analysis and interpretation of both language and context. However, technology development is not accompanied by increased human resources in utilizing technology, especially in teaching-learning activities. Some teachers prefer the conventional way of teaching and learning activity. The researcher found that technological development was not accompanied by some teachers' ability to utilize the existing technology; they were rare to use any technical media to support their teaching-learning process.

Therefore, to exploit the existing technology, the researchers decided to make a teaching material to solve the problems by using PowerPoint. Multimedia is one of the media that is often used as a medium of learning. It is a means of media through computers that present sound, text, animation, audio, and video. Powerpoint is one of the features available for a media presentation by using several existing slides. This

Uray Siti Annisa Ravi Ardha, Ikhsanudin Ikhsanudin, Luwandi Suhartono|23 
application is much simplified and widely used by various groups, both students and people with other occupations, even though its existence is long enough, but not everyone can use it well. However, PowerPoint can still efficiently operate for people who do not know how to create any media through this application.

Concerning the use of multimedia (PowerPoint) as a learning medium, other researches conducted by Ramadanti, Salam, and Arifin (2016) and Maulana, Ikhsanudin, and Wardah (2019) found that the use of PowerPoint was beneficial in teaching and learning, and it could improve students' interest and motivation in learning. Ramadanti, et al. (2016) developed The PAT Alphabet to support teaching writing descriptive text, whereas Maulana, et al. (2019) developed The E-PON to teach narrative text in Senior High School. The studies' findings revealed that PowerPoint could help students solve problems encountered during the text learning process. It also helped teachers enrich learning material related to existing topics and strongly supports teaching and learning activities rather than using books alone.

The researcher attempts to make teaching materials to help teachers and students in teaching-learning activity from the explanation above. When the two previous studies focused on descriptive and narrative text, this research focused on analytical exposition text and writing skills. The researcher designed the material called "Materials of Analytical Exposition Text (MOWAET)." This material intends to support the teaching and learning process to become easier and bring them into a new atmosphere in learning analytical exposition text. The researcher used ADDIE by Branch (2009) to create the materials, but this research only used three steps of ADDIE, which are analyzing, designing, and developing.

\section{METHOD}

The researcher used Research and Development method to develop a new product to solve the problem. The researcher used ADDIE as the design model. It is proposed by Branch (2009). ADDIE consists of five steps, namely analyzing, designing, developing, implementing, and evaluating. However, the researcher only used three ADDIE steps, which were analyzing, designing, and developing.

Analyzing was the first step to develop the product. It was a stage recognizing the possibility of the causes of the performance gap in the learning process (Branch, 2009). In this stage, the researcher interviewed the teacher and observed the students. The researcher used an unstructured - interview. It was conducted to get information about the teacher's needs, problems, and facilities used in the teaching-learning process. The details were about the current issues of teaching and learning, the syllabus, the available teaching materials, instructional tools in the teaching of analytical exposition text, and the writing mastery of the eleventh-grade students.

In the analyzing phase, the first step that the researcher did was, analyzed the book used by the teacher and the students, which was "Belajar Praktis Bahasa Inggris by Viva Pakarindo." In the second step, to gather information about teaching and learning in writing activities, the researcher collected some data through interviewed the English teacher. After that, the researcher coded the interview result and developed the requirement based on the need for supplementary teaching materials. After that, the researcher designed the criteria that included the requirement of appropriate material to do an internal evaluation in the development phase. 
The design stepbased on the interview results and the book analyzed as the guideline for developing and managing the product. The researcher used the theory by Richards and Rodgers (2001) in the designing phase in the language teaching process: (a) the objectives of the method; (b) the types of learning tasks and teaching activities; (c) the role of the learners; (d) the teachers' roles; and (e) theinstructional material's roles. Core competencies have become a consideration that underlies the teaching of English at senior high school. In the designing process, the researcher created the materials by selecting and adapting the materials from the internet, and the researcher made some materials. Some materials outside the book have been added to complete the activities.The researcher designed a flow chart to draw the flow and sequence of the product.The researcher has drawn up criteria that include the requirements of appropriate materials to carry out an internal evaluation during the development process.

The researcher used a Powerpoint presentation and the Animaker website to develop the supplementary teaching materials. According to Branch (2009), the design phase aims to verify the designed performances and appropriate testing methods. The design process should answer whether it is possible to use the product designed or not to solve this study's problem.

Developing was the last step used in this research. Three stages have been performed in this phase. The first step was collecting materials such as texts, pictures, animation, audio, and props. After finishing collecting the materials and the product components, the next step was integrating them into materials of writing analytical exposition text (MOWAET) using PowerPoint. After that, the researcher created the listening audio by using the website "Animaker." The last step was the internal evaluation. The internal evaluation was the most decisive step of the phase. According to Harvey (2004), internal evaluation is a process of a quality review undertaken within an institution for its ends (with or without external peers' involvement). The researcher checked and observed the product to ensure thatthe product fulfills all aspects of the criteria.

\section{RESULTS AND DISCUSSION}

\section{Result}

To get information about the eleventh-grade students' characteristics, including their needs, the researcher conducted a need survey. The need survey was achieved through the English teacher's interview as the one who closes with the students. The resulting interview data are; (1)The students were not interested and lacked attention during the learning process. (2)The students had difficulties in writing analytical exposition text following the structures of the text. (3)The eleventh-grade students' writing ability was below average. (4)Defective materials in the teaching process. (5)The Materials of Analytical Exposition Text (MOWAET) would help encourage the students to learn analytical exposition text and give students a more entertaining way.

In conclusion, the book's materials were not sufficiently comprehensive for the teacher and the students, as there was only a brief explanation of the analytical exposition text and a few exercises. It was necessary to find new and fun materials to be taught in the classroom to draw the students' attention. The curriculum also needed new supporting teaching materials and help the students in learning analytical exposition text.

Uray Siti Annisa Ravi Ardha, Ikhsanudin Ikhsanudin, Luwandi Suhartono|25 
The researcher developed this product to address students' analytical exposition text needs of eleventh grade in the teaching and learning process. During this phase, the researcher collected more comprehensive materials from internet literature, books, etc. The next step was developing. The researcher began developing the product using the software chosen from the previous phase. The software used was "Microsoft PowerPoint 2013" and "Animaker." The process of the developing phase consisted of developing, internalevaluation, small-scale implementation, and revision.

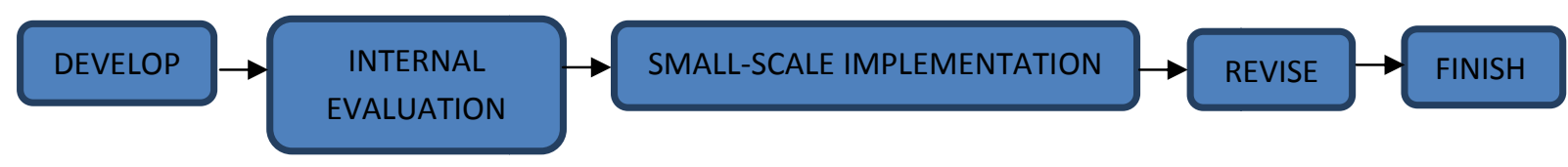

Picture 1. Developing Process

Upon designing the product, the researcher decided whether or not the product met the criteria. The researcher did the internal evaluation to ensureno bias; the researcher implemented the product with a small group of participants. The participants were ten $8^{\text {th }}$ semester students of the English Education Study Program.

The first thing that the researcher did was working with Microsoft Powerpoint 2013. Powerpoint provided many background styles in the theme to be chosen. The props also were made in line with the appropriateness of teaching and learning stuff. Besides, the researcher took the props from other sources. Powerpoint also provided many features to help the researcher design the MOWAET. It made the researcher more comfortable in creating MOWAET.

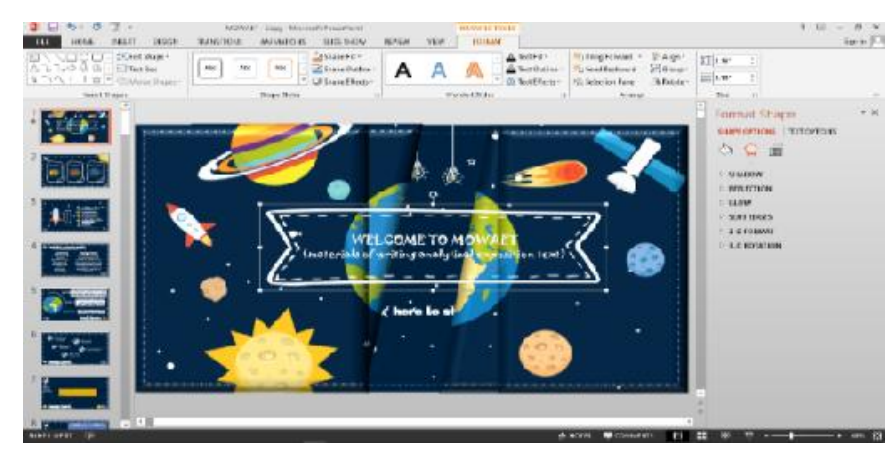

Picture 2. Working with Microsoft Powerpoint 2013 for Background

During this process, the researcher also edited the movement of the texts and slides. Adding some pictures to complete the visual of the slide was also done by the researcher.After designing the background and adding the slides and text's movement, the researcher inserted the materials and chose several fonts.The fonts were readable and nice-looking, and also the choice of many fonts aimed to make the text on the slide not monotonous, were the reasons why the researcher used it in the MOWAET.

After the researcher finished the teaching material parts, the researcher worked with the texts' audio. The replenishment of audio aimed to be part of the listening practice. To create the voice, the researcher used "Animaker" with the Animaker voice feature by inserting the text in the provided clipboard and edited it before downloading 
the audio. In this process, the researcher altered the audio by adjusting the speed, pitch, and volume, and also the voice's gender. Besides that, the user could choose six levels for the level of speed, pitch, and volume.

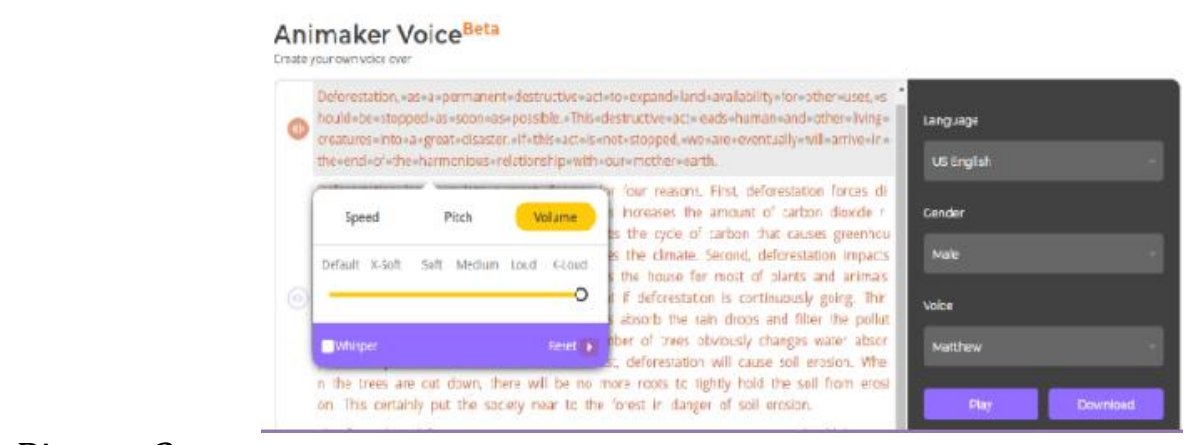

Picture 3.

\section{Animaker for Audio}

Working with

The researcher did an internal evaluation to ensure that the product is usable. Branch (2009) stated that reasonable learning goals should reflect the reality in which students will be expected to perform. They should maintain a high degree of unity between the learning space and the place where actual tasks are completed. Moreover, the researcher developed the product and the internal evaluation phase was conducted. The researcher measured the product's usability by using criteria that have been made in the designing phase. The researcher evaluated and observed the product objectively by using these criteria.

Based on the first internal evaluation result, the researcher found some problems with the product. The first one was the materials were not well organized and structured. To make the teacher more comfortablepresenting the material with a proper sequence, the researcher changed the home menu with three main menus: materials, exercises, and the user's guide. Some buttons were not working well, and the text used in the product was not visible. When the researcher asked the ten $8^{\text {th }}$ students of the English Study Program, they said that some buttons could not work, and there was some text changed from the original form of the product. So the researcher also revised for that problem.

Table 1. The Final Result of Internal Evaluation

\begin{tabular}{|c|l|c|c|}
\hline No. & \multicolumn{1}{|c|}{ Criterion/Aspects } & Yes & No \\
\hline $\mathbf{1 .}$ & The materials support and relate to the 2013 curriculum & $\sqrt{ }$ & \\
\hline $\mathbf{2 .}$ & The level of difficulty is appropriate for the students & $\sqrt{ }$ & \\
\hline $\mathbf{3 .}$ & The exercises and activities are based on the learning objectives & $\sqrt{ }$ & \\
\hline $\mathbf{4 .}$ & $\begin{array}{l}\text { The teaching media do not show any bias (social, belief system, gender, } \\
\text { etc.) }\end{array}$ & $\sqrt{ }$ & \\
\hline $\mathbf{5 .}$ & The materials are well organized and structured & $\sqrt{ }$ & \\
\hline
\end{tabular}




\begin{tabular}{|c|l|c|c|}
\hline 6. & All the contents are grammatical & $\sqrt{ }$ & \\
\hline 7. & The materials are focus on analytical exposition text & $\sqrt{ }$ & \\
\hline $\mathbf{8 .}$ & The buttons are consistent and structured & $\sqrt{ }$ & \\
\hline 9. & The text used in the multimedia is visible & $\sqrt{ }$ & \\
\hline 10. & Volume and quality of sound are clear & $\sqrt{ }$ & \\
\hline 11. & Visuals are appropriate and clear & $\sqrt{ }$ & \\
\hline 12. & The buttons are working well & $\sqrt{ }$ & \\
\hline 13. & There is a user's guide & $\sqrt{ }$ & \\
\hline 14. & There is a booklet of the product & \\
\hline
\end{tabular}

\section{Discussion}

Encouraging the eleventh-grade students to learn the analytical exposition text using suitable instructional resources has become a teacher's obligation in the teaching and learning process.Unfortunately, based on the interview result with the English teacher in the analyzing phase, there were some problems during the classroom teaching process. The problem was that the student's participation and motivation in the teaching and learning process were meager and uneven. It made the eleventh-grade students' writing mastery, especially in writing analytical exposition text, was still below average. Moreover, the teachers' teaching sources were not completed enough to support the teaching process and encourage them to learn.

In line with the problem found in the analyzing phase, Andresen and Brink (2013) bring up Multimedia that combines pictures, sound, video, animation, and simulations of learning material are more appealing to many forms of learning, as some students will gain more from learning by reading, some by listening, some by watching, and so on. They became the researcher's incentives to design materials of writing analytical exposition text (MOWAET) as supplementary teaching materials to support the teaching and learning process.

In designing appropriate multimedia instruction, Reddi and Misra (2003) pointout several elements that must be considered by the researcher: they were the objectives, the content, media options, and the evaluation option. The first element was the need to specify the objectives of the materials of analytical exposition text. This researcher's domain objective was to provide eleventh-grade students with enjoyable supplementary teaching materials for learning analytical exposition text and alternative additional teaching materials based on the syllabus.

The researcher also confirmed the supplementary teaching materials with the 2013 curriculum used by the target school. Following that, the researcher found that on several competencies in designing the materials of analytical exposition text. In the first competency, the students were able to capture the contextual meaning of social functions, the text's structure, and the linguistic element of the oral and written 
analytical exposition related to the actual issue. The second competency was the students were able to compose the text of the written analytical exposition, associated with the real problem, concerning social functions, text structures, and the linguistic elements, correctly and in context. Conforming the supplementary teaching material was a fundamental part of this research because it showed the objectives that had to be achieved.

Contents of the designed materials of writing analytical exposition text were the second element. This study's content was created to support the analytical exposition text learning and teaching process of the scientific approach in the 2013 curriculum. Besides, the content must adjust to the student's level of learning. The materials in the MOWAET were designed in a more accessible format and interesting for eleventh-grade students. Adjusting the materials with the student's level of English learning ability would help them not feel a burden in learning analytical exposition text. Besides, the materials also must in line with the learning objective and the teacher's need.

The third element wasmedia options. It was necessary to choose the correct media to achieve the learning objectives by using multimedia that integrates audio, animation, etc.According to Akrim(2018),the proper learning media in the teaching andlearning process will produce a satisfactory outputincluding the change in the behavior of students.For this research, the researcher decided to develop a product that would incorporate audio and animation to support teaching and learning the materials. The researcher chose to use two software to create the product, and it was focused on the functionality of the software itself. The first software was "Microsoft PowerPoint," a kind of interactive presentation consisting of text, graphics, pictures, sounds, and videos that can be used to communicate content in the teaching and learning process. This software also included many tools to create a good slide, which could be paired with other software, helping develop the product. The researcher would also be able to edit each slide of the sample before exporting it to an entire electronic presentation. The other software was "Animaker," a Text-To-Speech (TTS) website that allowed the user to create voices from words or texts entered. The researcher used this software to establish an external voice over the electronic presentation. In this research, the researcher used the internal evaluation. The researcher used an internal evaluation to identify the usability of this electronic presentation to the user.

This research's difficulties were to present the materials as simply as possible but do not diminish the original one's real meaning. It was not less explanation from the textbook used. This product was created to make a new teaching source for students and make the circumstance of learning interesting and exciting, so the materials presented should not be the same as the textbook that they used, although the materials were the same.

However, despite the difficulties faced, this product's strength is the animated visual that makes students interested in learning the materials. It could attract student's attention better than just an abstract word. The visual of the product is contrast and visible. No text is sized less than 12 to make the students more comfortable seeing every content in the product. The text and the button is working well to go to the wanted materials. The product's materials also provided another explanation when the textbook did not, so the students could easily understand the materials. 
Nonetheless, there is some limitation on this product. There are only two kinds of exercises supporting writing practices: the exercise of analytical exposition text structure and writing analytical exposition text. Even these exercises are enough to help the students write their analytical exposition text, but it will be better for the materials to have many kinds of writing exercises. Different writing exercises will help them see different ways to write analytical exposition text, whether it is based on the generic structure, language feature, or other elements that include writing analytical exposition text.

\section{CONCLUSION AND SUGGESTIONS}

\section{Conclusion}

Regarding the research finding, the researcher encapsulated the conclusion of the research. The Materials of Writing Analytical Exposition Text (MOWAET) are usable so theycan be applied in the classroom to support teaching and learning analytical exposition text proven by the final evaluation of the MOWAET which washad no reasons to carry out a formative revision. The three kinds of exercises of MOWAET, such as multiple-choice, the exercises of structure, and the exercises of writing analytical exposition text can help the student to achieve the learning goals. They are more engaged in the learning activity and also able to construct the learning information.

\section{Suggestions}

There are some suggestions addressed to the English teachers, eleventh-grade students, and materials of writing analytical exposition text developers. (1) English teachers are suggested to develop various classroom activities using Information Communication and Technology (ICT) in the teaching and learning process. (2) The students are expected to use this product to help them in learning analytical exposition text. (3) Considering the improvement of the materials of writing analytical exposition text, the researcher suggests the other researchers add different kinds of writing exercises to give students as much as possible the exercises that help students writing analytical exposition text. For improving the materials of writing analytical exposition text, using the "Microsoft PowerPoint" and "Animaker" software to create a supplementary teaching media is suggested. It is an ideal software for the beginner or advanced user to make any additional teaching media.

\section{REFERENCES}

Akrim. (2018). Media Learning in Digital Era. Proceeding of the 5th International Conference on Community Development (AMCA). 458-460. https://doi.org/10.2991/amca-18.2018.127.

Andresen, B. B., \& Brink, K. V. D. (2013). Multimedia in Education Curriculum.Moscow: UNESCO Institute for Information Technologies in Education.

Branch, R. M. (2009). Instructional Design: The ADDIE Approach. New York: Springer.

Ang, T. C.,\& Mohamad, M. (2014). A Study of Visual Design in PowerPoint Presentation Slide and Its Relationship with Postgraduate Learner Engagement and Satisfaction. International Proceedings of Economics Development and Research (IPEDR). 78(18). 91-96.DOI: 10.7763/IPEDR. 2014. V 78. 18.

Harvey, L. (2004). Analytic Quality Glossary. Quality Research International. Retrieved from: http://www.qualityresearchinternational.com/glossary/. 
Joshi, A. (2012). Multimedia: A Technique in Teaching Process in The Classrooms. Current World 33.DOI:http://dx.doi.org/10.12944/CWE.7.1.05.

Maulana, A., Ikhsanudin., \& Wardah. (2013). Designing 'E - Pon' To Teach Narrative Text in Senior High School. Jurnal Pendidikan dan Pembelajaran Khatulistiwa. 8(10), 110.

Ramadanti, R. M., Salam, U., \& Arifin, Z. (2016). Designing the P. A. T Alphabet to Support Teaching Writing Descriptive Text. Jurnal Pendidikan dan Pembelajaran Khatulistiwa, 5(9). 1-15.

Ratnaningsih, E. (2016). Improving Students' Writing Ability through The Use of Dictogloss Technique. Transformatika: Jurnal Bahasa, Sastra, dan Pengajarannya, 12(2).

14.DOI: http://dx.doi.org/10.31002/transformatika.v12i2.186.

Reddi, U. V., \& Mishra, S. (2003). Educational multimedia: AHandbook for Teacher Developers. New Delhi: Commonwealth Educational Media Centre for Asia (CEMCA).

Richards, J. C., \& Rodgers, T. S. (2001). Approaches and Methods in Language Teaching. New York: Cambridge University Press. 